\title{
Impaired skeletal growth in mice with haploinsufficiency of IGF-I: genetic evidence that differences in IGF-I expression could contribute to peak bone mineral density differences
}

\author{
S Mohan ${ }^{1-4}$ and D J Baylink ${ }^{1,2}$ \\ ${ }^{1}$ Musculoskeletal Diseases Center, JLP Veterans Administration Medical Center, 11201 Benton St, Loma Linda, California 92357, USA \\ ${ }^{2}$ Departments of Medicine, ${ }^{3}$ Biochemistry and ${ }^{4}$ Physiology, Loma Linda University, Loma Linda, California 92354, USA \\ (Requests for offprints should be addressed to S Mohan; Email: Subburaman.Mohan@med.va.gov)
}

\begin{abstract}
Although it is well established that there is considerable inter-individual variation in the circulating levels of IGF-I in normal, healthy individuals and that a genetic component contributes substantially to this variation, the direct evidence that inter-individual variation in IGF-I contributes to differences in peak bone mineral density (BMD) is lacking. To examine if differences in IGF-I expression could contribute to peak BMD differences, we measured skeletal changes at days 23 (prepubertal), 31 (pubertal) and 56 (postpubertal) in mice with haploinsufficiency of IGF-I $(+/-)$ and corresponding control mice $(+/+)$. Mice (MF1/DBA) heterozygous for the IGF-I knockout allele were bred to generate $+/+$ and $+/-$ mice $(n=18-20$ per group). Serum IGF-I was decreased by $23 \%(P<0 \cdot 001)$ in mice with IGF-I haploinsufficiency $(+/-)$ group at day 56 compared with the control $(+/+)$ group. Femoral bone mineral content and BMD, as determined by dual energy X-ray absorptiometry, were reduced by $20 \%(P<0 \cdot 001)$
\end{abstract}

and $12 \%$ respectively in the IGF-I $(+/-)$ group at day 56 compared with the control group. The peripheral quantitative computed tomography measurements at the femoral mid-diaphysis revealed that periosteal circumference $(7 \%$, $P<0 \cdot 01)$ and total volumetric $\operatorname{BMD}(5 \%, P<0 \cdot 05)$ were decreased significantly in the $+/-$ group compared with the $+/+$ group. Furthermore, serum IGF-I showed significant positive correlations with both areal BMD $(r=0.55)$ and periosteal circumference $(r=0.66)$ in the pooled data from the $+/+$ and $+/-$ groups. Our findings that haploinsufficiency of IGF-I caused significant reductions in serum IGF-I level, BMD and bone size, together with the previous findings, are consistent with the notion that genetic variations in IGF-I expression could, in part, contribute to inter-individual differences in peak BMD among a normal population.

Journal of Endocrinology (2005) 185, 415-420

\section{Introduction}

The risk of developing senile osteoporosis in men and postmenopausal osteoporosis in women is, in large part, determined by the amount of bone mass accumulated during the active growth phases early in life. In terms of the potential regulatory molecules that contribute to the acquisition of peak bone mineral density (BMD) during postnatal growth, insulin-like growth factor-I (IGF-I) has received considerable attention for a number of reasons, including: (1) the effects of growth hormone $(\mathrm{GH})$ on skeletal growth are largely mediated via IGF-I (Kasukawa et al. 2004); (2) mice lacking a functional IGF-I gene exhibit severe impairment in bone formation and a severe deficiency in peak BMD (Bikle et al. 2001, Mohan et al. 2003); (3) osteoblast-specific knockout of the IGF receptor gene exhibits a decrease in cancellous bone volume, connectivity and trabecular number (Zhang et al. 2002);
(4) transgenic overexpression of GH or IGF-I leads to an increase in bone accretion (Saban et al. 1996, Zhao et al. 2000, Eckstein et al. 2004); (5) a congenic mouse containing a chromosome 6 serum IGF-I quantitative trait locus (QTL) region from a $\mathrm{C} 3 \mathrm{H} / \mathrm{HeJ}$ mouse into the C57BL/6J background exhibited a decrease in serum IGF-I and femoral BMD (Bouxsein et al., 2002); (6) IGF-I is required for the anabolic actions of parathyroid hormone on mouse bone (Miyakoshi et al. 2001, Bikle et al. 2002); and (7) insulin receptor substrate-1 knockout (KO) mice exhibited an insufficient proliferation of chondrocytes, calcification of hypertrophic chondrocytes, acceleration of apoptosis and early closure of the growth plate (Hoshi et al. 2004). Thus, there is strong evidence that IGF-I production is a major regulator of bone mass in mice.

There is also evidence that IGF-I plays an important role in the regulation of peak bone mass in men and women. In this regard, an adolescent male lacking a 
functional IGF-I gene had a BMD of 5 S.D. less than corresponding age-matched normal children (Woods et al. 1997). Furthermore, we and others have shown that serum levels of IGF-I increase during puberty and correlate with BMD (Moreira-Andres et al. 1995, Libanati et al. 1999, Thorsen et al. 1999, Richman et al. 2001, Kasukawa et al. 2003). Although recent studies provide evidence that both the variation in peak BMD and circulating levels of IGF-I are largely determined genetically (Harrela et al. 1996, Recker \& Deng 2002, Baldock \& Eisman 2004), the direct experimental evidence for the hypothesis that genetic-dependent variation in IGF-I production is a major determinant of the variation in peak BMD seen in normal healthy individuals is lacking at the present time. If differences in IGF-I expression caused by genetic alterations do indeed influence peak bone mass, then haploinsufficiency should lead to decreased IGF-I levels and a corresponding decrease in BMD. We therefore generated heterozygous IGF-I KO mice and corresponding control mice to evaluate the consequence(s) of half-normal gene expression on bone accretion. This study is an extension of a previous study (Mohan et al. 2003) which compared skeletal phenotypes of homozygous IGF-I KO mice with wild-type mice.

\section{Materials and Methods}

\section{Animals}

Heterozygous breeder MF1/DBA IGF-I KO mice (kindly provided by Dr Argiris Efstradiatis, Columbia University College of Physicans and Surgeons, New York, USA) were mated to generate heterozygous IGF-I KO and wild-type mice as described previously (Mohan et al. 2003). Heterozygous IGF-I KO and corresponding control littermate mice were killed at day 23 (before puberty), day 31 (at the end of puberty) and day 56 (post puberty) to collect bones for phenotypic measurements and serum for IGF-I measurements.

\section{Bone densitometry}

Femur BMD and bone mineral content (BMC) measurements were performed by dual energy X-ray absorptiometry, using the PIXImus instrument (LUNAR Corporation, Madison, WI, USA). The precision was $\pm 1 \%$ coefficients of variation (C.V.) in vitro and $\pm 2 \%$ C.V. in vivo.

\section{Volumetric bone density and geometric parameters of the femur}

The length of the femur was measured with calipers. Volumetric bone density and geometric parameters at the mid-diaphysis were determined by peripheral quantitative computed tomography as described (Mohan et al. 2003).

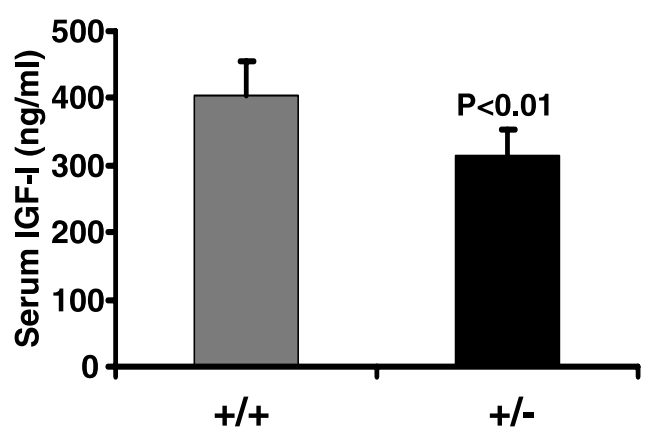

Figure 1 Serum IGF-I levels in heterozygous IGF-I KO and control mice at 8 weeks of age. Values are means \pm S.D. and represent an $n$ of $18-20$ per group.

The C.V. for total BMD and periosteal circumference for repeat measurements of four mouse femur (two to five measurements) were less than $3 \%$ and $1 \%$ respectively (Mohan et al. 2003).

\section{IGF-I RIA}

IGF-I was measured by specific RIA using rabbit polyclonal antiserum and recombinant IGF-I as standard and tracer respectively. IGF-binding proteins (IGFBP) were removed from serum prior to RIA by an acid gel filtration protocol (Mohan \& Baylink 1995).

\section{Statistics}

All values are expressed as means \pm S.D. Statistical analyses of the data were performed by Student's unpaired $t$-test.

\section{Results}

Serum IGF-I levels were reduced by 23\% $(P<0 \cdot 001)$ in heterozygous IGF-I KO mice compared with control mice (Fig. 1). Body weight was decreased by $14.5 \%(P<0 \cdot 01)$ in IGF-I +/ - mice compared with corresponding control mice at 8 weeks of age (data not shown). Accordingly, femur length was significantly reduced $(P<0 \cdot 01)$ in heterozygous IGF-I KO mice compared with control mice (Fig. 2). Both the body weight and femur length were reduced to a similar extent in the male and female heterozygous IGF-I KO mice compared with corresponding control mice. The rate of gain in femur length was reduced by $10 \%$ during puberty in the heterozygous IGF-I KO mice compared with control mice (data not shown).

Femoral BMC was reduced by $25 \%(P<0 \cdot 001)$ at days 23 and 31 in heterozygous IGF-I KO mice compared with control mice. The reduction in femoral BMC was $20 \%$ $(P<0 \cdot 001)$ at day 56 in heterozygous IGF-I KO mice compared with control mice (Fig. 3). The rate of gain in femoral BMC was reduced by $25 \%$ in heterozygous IGF-I 


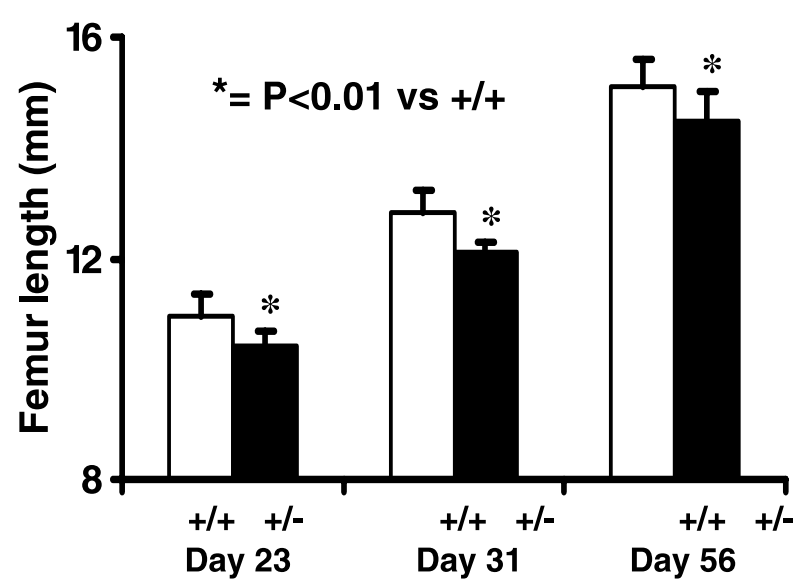

Figure 2 Femur length in heterozygous IGF-I KO and control mice during postnatal growth. Values are means \pm S.D. and represent an $n$ of $18-20$ per group.

KO mice compared with control mice during puberty (data not shown), suggesting that IGF-I plays a critical role in regulating the bone accretion that occurs during puberty.

Femoral BMD was reduced by $7 \%, 12 \%$ and $11 \%$ respectively at days 23, 31 and 56 in the heterozygous IGF-I KO mice compared with control mice (Fig. 4). The rate of gain in areal BMD was reduced by $24 \%$ in heterozygous IGF-I KO mice compared with control mice during puberty (data not shown), suggesting that IGF-I plays an important role in regulating BMD during sexual maturation.

Total volumetric BMD (vBMD) showed no variation between heterozygous IGF-I KO and control mice at day 23. Total $\mathrm{vBMD}$ was decreased by $9 \%$ and $4 \%$ respectively in heterozygous IGF-I KO mice compared with control mice at days 31 and 56 (Fig. 5). The rate of gain in total

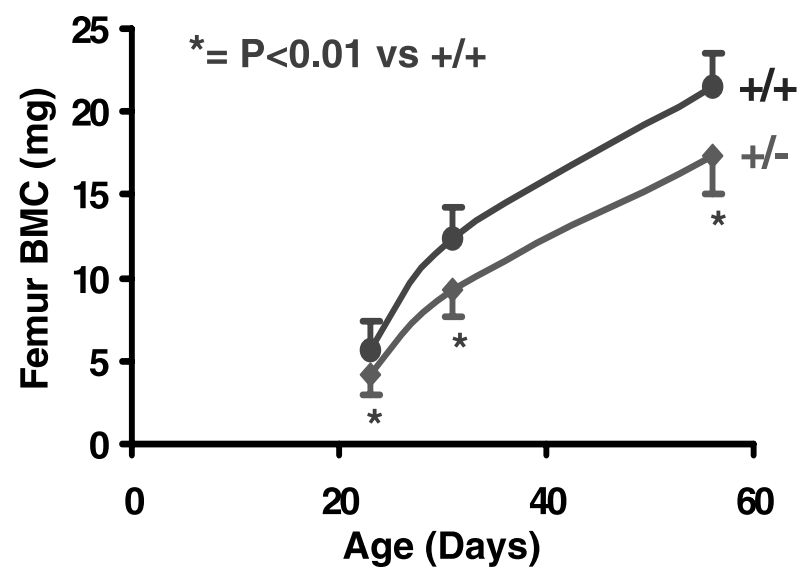

Figure 3 Femoral BMC in heterozygous IGF-I KO and control mice during postnatal growth. Values are means \pm S.D. and represent an $n$ of 18-20 per group.

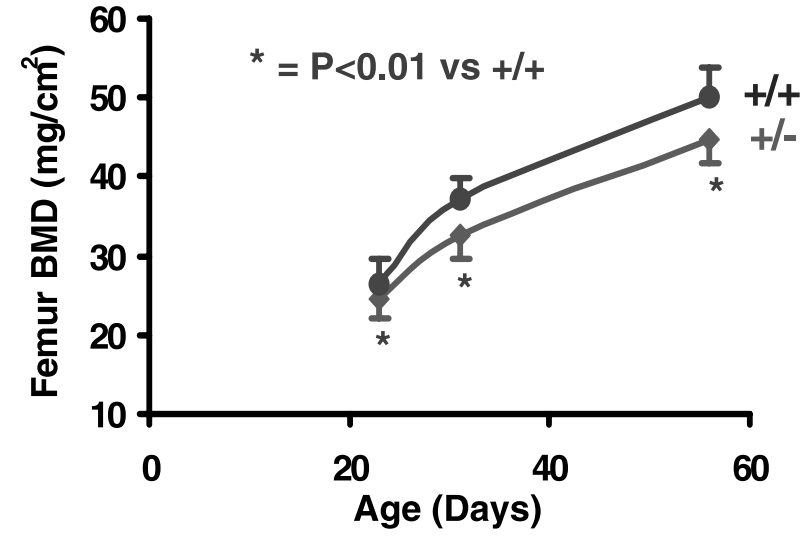

Figure 4 Femur areal BMD in heterozygous IGF-I KO and control mice during postnatal growth. Values are means \pm S.D. and represent an $n$ of 18-20 per group.

vBMD was reduced by $34 \%$ in heterozygous IGF-I KO mice compared with control mice during puberty (data not shown). There was no gender difference in the total vBMD deficit of heterozygous IGF-I KO mice (data not shown).

Femoral periosteal circumference was reduced by $7 \%$ in heterozygous IGF-I KO mice compared with control mice at days 23, 31 and 56 (Fig. 6). The magnitude of reduction in periosteal circumference was similar in male and female heterozygous IGF-I KO mice compared with control mice (data not shown). The rate of gain in periosteal circumference was not significantly different between the heterozygous IGF-I KO and control mice during puberty.

Serum levels of IGF-I showed a significant positive correlation with areal BMD of the femur in heterozygous IGF-I KO mice and control mice (Fig. 7). Serum levels of IGF-I also showed a significant positive correlation with the periosteal circumference of the femur in both the heterozygous IGF-I KO mice and control mice (Fig. 8).

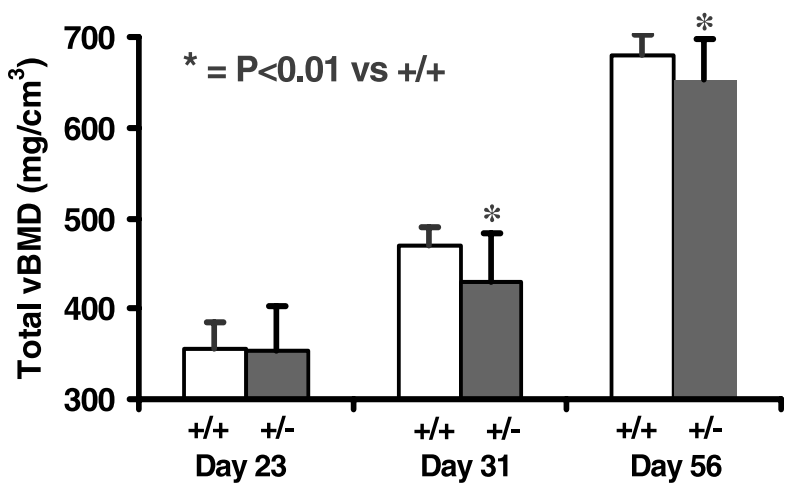

Figure 5 Femur total $\mathrm{vBMD}$ in heterozygous IGF-I KO and control mice during postnatal growth. Values are means \pm s.D. and represent an $n$ of $18-20$ per group. 


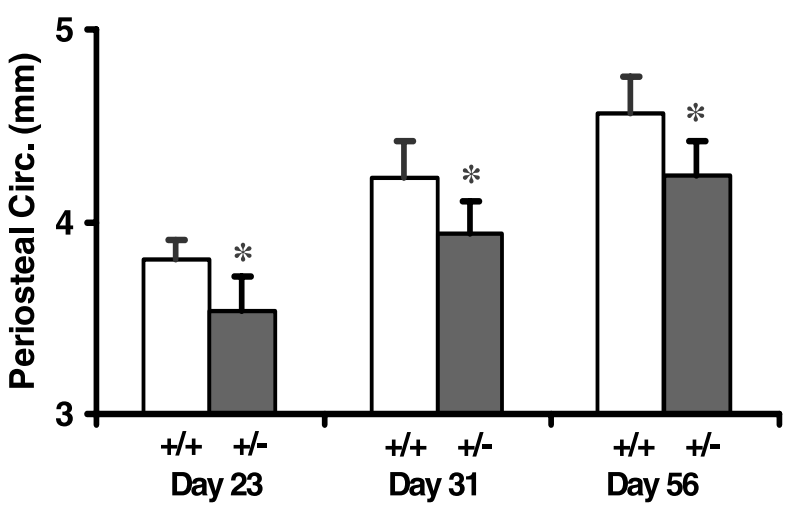

Figure 6 Periosteal circumference (Circ.) of the femur in heterozygous IGF-I KO and control mice during postnatal growth. Values are means \pm S.D. and represent an $n$ of 18-20 per group.

\section{Discussion}

The findings of this study have demonstrated for the first time that haploinsufficiency of IGF-I caused a significant reduction in serum IGF-I level in mice. If both copies of the IGF-I gene contribute equally to the level of serum IGF-I, we would anticipate the serum IGF-I level to be reduced by $50 \%$ in the heterozygous IGF-I KO mice

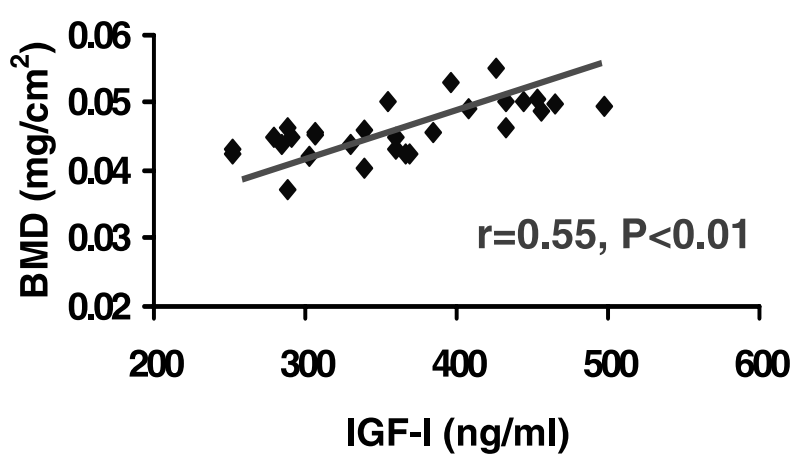

Figure 7 Correlation between areal BMD of femur and serum levels of IGF-I in heterozygous IGF-I KO and control mice at 8 weeks of age.

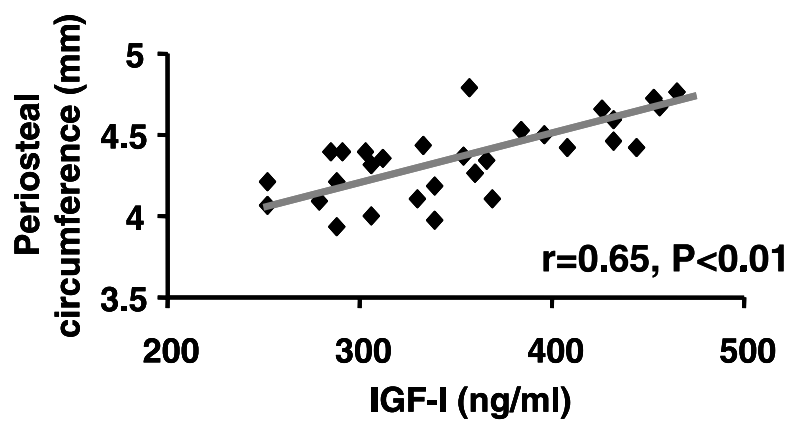

Figure 8 Correlation between periosteal circumference of femur and serum levels of IGF-I in heterozygous IGF-I KO and control mice at 8 weeks of age. compared with control mice. However, the magnitude of reduction in IGF-I was only about $25 \%$ in the mice with haploinsufficiency compared with 100\% in homozygous IGF-I KO mice. There are a number of potential explanations for the less-than-anticipated reduction in circulating IGF-I, which include: (1) the lower IGF-I production in the heterozygous mice may lead to diminished negative feedback on the production of GH-releasing hormone and $\mathrm{GH}$ by the hypothalamus and the pituitary respectively (Mohan \& Baylink 1999); (2) increased proportion of circulating IGF-I may be bound to acid labile subunit (ALS) and IGFBP-3/IGFBP-5 in the heterozygous mice which would increase the half-life of circulating IGF-I (Rajaram et al. 1997); and (3) two copies of the IGF-I gene may not produce twice the amount of IGF-I compared with a single copy of the IGF-I gene. Future studies are needed to establish the extent to which the expression of IGF-I is reduced in various tissues compared with serum levels of IGF-I in heterozygous mice.

This study also demonstrated for the first time that a $25 \%$ reduction in circulating IGF-I caused by haploinsufficiency of IGF-I led to significant reductions in total vBMD (4\%) and bone size (7\%) in the femur in mice at 8 weeks of age. Consistent with these data, Bouxsein et al. (2002) have recently shown that a congenic mouse strain with a donated segment from a $\mathrm{C} 3 \mathrm{H} / \mathrm{HeJ}$ mouse into a C57BL/6J mouse had 11-21\% lower IGF-I levels and $2 \cdot 3-4 \cdot 8 \%$ lower total femoral vBMD. The magnitude of reductions in BMD and/or bone size in IGF-I heterozygous mice and congenic mice were far less compared with IGF-I KO mice in which both copies of the IGF-I gene were disrupted (32\% and $43 \%$ reduction in BMD and bone size respectively). These data raise the possibility that while a small reduction in IGF-I expression (10-20\%) produces a significant effect on both BMD and bone size, two important determinants of bone strength, a reduction in IGF-I expression below a certain threshold level may contribute to a much more dramatic effect on the skeletal phenotype. In this regard, it was recently reported that the lowering of serum IGF-I below a threshold by crossing liver-derived IGF-I KO mice with ALS KO mice produced a dramatic effect on bone size which was not seen in either liver-derived IGF-I KO mice or ALS KO mice alone (Yakar et al. 2002).

In previous studies, we and others have shown that circulating levels of IGF-I vary considerably in normal healthy men and women between 20-40 years of age (Rajaram et al. 1997). Although variation in circulating levels of IGF-I may be regulated by a number of variables, including diet and exercise, there is considerable evidence for the involvement of genetic regulation of variation in serum IGF-I levels. Rosen et al. (1998) first reported that serum IGF-I levels are related to a polymorphism in a microsatellite within the IGF-I gene in healthy Caucasian men and women. Several subsequent studies have confirmed the association between IGF-I polymorphisms and 
circulating IGF-I levels (Johnston et al. 2003, Rietveld et al. 2003, 2004, Nielsen et al. 2004). Based on these data, it can be concluded that genetic variation in IGF-I expression caused by polymorphism in one or more genes involved in regulating IGF-I expression and/or its action could contribute to inter-individual variations in peak BMD among a normal population.

The conclusion that differences in IGF-I expression could contribute to peak BMD differences in humans should be viewed in the following context. (1) IGF-I heterozygous mice and corresponding control mice were developed in mixed genetic backgrounds. Therefore, one could argue that the observed phenotypic differences between the heterozygous and control mice may be due to differences in genetic backgrounds. However, this is unlikely since we used corresponding control littermates, but of the same mixed genetic background, mice from several litters and a large number of mice $(n=18-20)$ per group in our studies. (2) It is known that differences in bone size can influence BMD measurements. Because the bone size of IGF-I heterozygous mice is slightly smaller compared with wild-type mice, the estimated magnitude of reduction in BMD in IGF-I heterozygous mice may not be precise. (3) While the findings in this study that haploinsufficiency of IGF-I leads to a reduction in BMD are consistent with previous studies using various transgenic mouse models regarding an important role for IGF-I in the regulation of peak bone mass in mice, the issue of whether genetic-dependent variation in IGF-I production is a major determinant of variation in peak BMD in normal healthy humans is still to be resolved.

\section{Acknowledgements}

We thank Dr Argiris Efstradiatis for providing us with breeding pairs of IGF-I and IGF-II KO mice. We would also like to acknowledge the technical assistance of Rongqing Guo and Alice Kramer. This work was supported by funds from NIH (AR31062 and 48139) and the US Army and National Medical Technology Testbed (NMTB) (Cooperative Agreement no. DAMD17-97-27016). The views, opinions and/or findings in this report are those of the authors and should not be construed as a position, policy, decision or endorsement of federal government or the NMTB. All work was performed in facilities provided by the Department of Veterans Affairs. The authors declare that there is no conflict of interest that would prejudice the impartiality of this scientific work.

\section{References}

Baldock PA \& Eisman JA 2004 Genetic determinants of bone mass. Current Opinion in Rheumatology 16 450-456.

Bikle D, Majumdar S, Laib A, Powell-Braxton L, Rosen C, Beamer W, Nauman E, Leary C \& Halloran B 2001 The skeletal structure of insulin-like growth factor I-deficient mice. Journal of Bone and Mineral Research 16 2320-2329.
Bikle DD, Sakata T, Leary C, Elalieh H, Ginzinger D, Rosen CJ, Beamer W, Majumdar S \& Halloran BP 2002 Insulin-like growth factor $\mathrm{I}$ is required for the anabolic actions of parathyroid hormone on mouse bone. Journal of Bone and Mineral Research 17 1570-1578.

Bouxsein ML, Rosen CJ, Turner CH, Ackert CL, Shultz KL, Donahue LR, Churchill G, Adamo ML, Powell DR, Turner RT et al. 2002 Generation of a new congenic mouse strain to test the relationships among serum insulin-like growth factor I, bone mineral density, and skeletal morphology in vivo. Journal of Bone and Mineral Research 17 570-579.

Eckstein F, Weusten A, Schmidt C, Wehr U, Wanke R, Rambeck W, Wolf E \& Mohan S 2004 Longitudinal in vivo effects of growth hormone overexpression on bone in transgenic mice. Journal of Bone and Mineral Research 19 802-810.

Harrela M, Koistinen H, Kaprio J, Lehtovirta M, Tuomilehto J, Eriksson J, Toivanen L, Koskenvuo M, Leinonen P, Koistinen R et al. 1996 Genetic and environmental components of interindividual variation in circulating levels of IGF-I, IGF-II, IGFBP-1, and IGFBP-3. Journal of Clinical Investigation 98 2612-2615.

Hoshi K, Ogata N, Shimoaka T, Terauchi Y, Kadowaki T, Kenmotsu S, Chung UI, Ozawa H, Nakamura K \& Kawaguchi H 2004 Deficiency of insulin receptor substrate-1 impairs skeletal growth through early closure of epiphyseal cartilage. Journal of Bone and Mineral Research 19 214-223.

Johnston LB, Dahlgren J, Leger J, Gelander L, Savage MO, Czernichow P, Wikland KA \& Clark AJ 2003 Association between insulin-like growth factor I (IGF-I) polymorphisms, circulating IGF-I, and pre- and postnatal growth in two European small for gestational age populations. Journal of Clinical Endocrinology and Metabolism 88 4805-4810.

Kasukawa Y, Baylink DJ, Wergedal JE, Amaar Y, Srivastava AK, Guo R \& Mohan S 2003 Lack of insulin-like growth factor I exaggerates the effect of calcium deficiency on bone accretion in mice. Endocrinology 144 4682-4689.

Kasukawa Y, Miyakoshi N \& Mohan S 2004 The anabolic effects of GH/IGF system on bone. Current Pharmacentical Design 10 2577-2592.

Libanati C, Baylink DJ, Lois-Wenzel E, Srinvasan N \& Mohan S 1999 Studies on the potential mediators of skeletal changes occurring during puberty in girls. Journal of Clinical Endocrinology and Metabolism 84 2807-2814.

Miyakoshi N, Kasukawa Y, Linkhart TA, Baylink DJ \& Mohan S 2001 Evidence that anabolic effects of PTH on bone require IGF-I in growing mice. Endocrinology 142 4349-4356.

Mohan S \& Baylink DJ 1995 Development of a simple valid method for the complete removal of insulin-like growth factor (IGF)-binding proteins from IGFs in human serum and other biological fluids: comparison with acid-ethanol treatment and C18 Sep-Pak separation. Journal of Clinical Endocrinology and Metabolism 80 637-647.

Mohan S \& Baylink DJ 1999 Role of growth hormone/insulin-like growth factor axis. In The Aging Skeleton, pp 209-219. Eds GJ Rosen \& JP Bilezikian. San Diego: Academic Press.

Mohan S, Richman C, Guo R, Amaar Y, Donahue LR, Wergedal J \& Baylink DJ 2003 Insulin-like growth factor regulates peak bone mineral density in mice by both growth hormone-dependent and -independent mechanisms. Endocrinology 144 929-936.

Moreira-Andres MN, Papapietro K, Canizo FJ, Rejas J, Larrodera L \& Hawkins FG 1995 Correlations between bone mineral density, insulin-like growth factor I and auxological variables. European Journal of Endocrinology 132 573-579.

Nielsen EM, Hansen L, Lajer M, Andersen KL, Echwald SM, Urhammer SA, Hansen T \& Pedersen O 2004 A common polymorphism in the promoter of the IGF-I gene associates with increased fasting serum triglyceride levels in glucose-tolerant subjects. Clinical Biochemistry 37 660-665.

Rajaram S, Baylink DJ \& Mohan S 1997 Insulin-like growth factor-binding proteins in serum and other biological fluids: regulation and functions. Endocrine Reviews 18 801-831. 
Recker RR \& Deng HW 2002 Role of genetics in osteoporosis. Endocrine 17 55-66.

Richman C, Kutilek S, Miyakoshi N, Srivastava AK, Beamer WG, Donahue LR, Rosen CJ, Wergedal JE, Baylink DJ \& Mohan S 2001 Postnatal and pubertal skeletal changes contribute predominantly to the differences in peak bone density between $\mathrm{C} 3 \mathrm{H} / \mathrm{HeJ}$ and $\mathrm{C} 57 \mathrm{BL} / 6 \mathrm{~J}$ mice. Journal of Bone and Mineral Research 16 386-397.

Rietveld I, Janssen JA, Hofman A, Pols HA, van Duijn CM \& Lamberts SW 2003 A polymorphism in the IGF-I gene influences the age-related decline in circulating total IGF-I levels. European Journal of Endocrinology 148 171-175.

Rietveld I, Janssen JA, van Rossum EF, Houwing-Duistermaat JJ, Rivadeneira F, Hofman A, Pols HA, van Duijn CM \& Lamberts SW 2004 A polymorphic CA repeat in the IGF-I gene is associated with gender-specific differences in body height, but has no effect on the secular trend in body height. Clinical Endocrinology $\mathbf{6 1}$ 195-203.

Rosen CJ, Kurland ES, Vereault D, Adler RA, Rackoff PJ, Craig WY, Witte S, Rogers J \& Bilezikian JP 1998 Association between serum insulin growth factor-I (IGF-I) and a simple sequence repeat in IGF-I gene: implications for genetic studies of bone mineral density. Journal of Clinical Endocrinology and Metabolism $\mathbf{8 3}$ 2286-2290.

Saban J, Schneider GB, Bolt D \& King D 1996 Erythroid-specific expression of human growth hormone affects bone morphology in transgenic mice. Bone 18 47-52.
Thorsen K, Nordstrom P, Lorentzon R \& Dahlen GH 1999 The relation between bone mineral density, insulin-like growth factor I, lipoprotein (a), body composition, and muscle strength in adolescent males. Journal of Clinical Endocrinology and Metabolism 84 3025-3029.

Woods KA, Camacho-Hubner C, Barter D, Clark AJ \& Savage MO 1997 Insulin-like growth factor I gene deletion causing intrauterine growth retardation and severe short stature. Acta Paediatrica $\mathbf{4 2 3}$ (Suppl) 39-45.

Yakar S, Rosen CJ, Beamer WG, Ackert-Bicknell CL, Wu Y, Liu JL, Ooi GT, Setser J, Frystyk J, Boisclair YR et al. 2002 Circulating levels of IGF-1 directly regulate bone growth and density. Journal of Clinical Investigation 110 771-781.

Zhang M, Xuan S, Bouxsein ML, von Stechow D, Akeno N, Faugere MC, Malluche H, Zhao G, Rosen CJ, Efstratiadis A et al. 2002 Osteoblast-specific knockout of the insulin-like growth factor (IGF) receptor gene reveals an essential role of IGF signaling in bone matrix mineralization. Journal of Biological Chemistry 277 44005-44012.

Zhao G, Monier-Faugere MC, Langub MC, Geng Z, Nakayama T, Pike JW, Chernausek SD, Rosen CJ, Donahue LR, Malluche HH et al. 2000 Targeted overexpression of insulin-like growth factor I to osteoblasts of transgenic mice: increased trabecular bone volume without increased osteoblast proliferation. Endocrinology 141 2674-2682.

Received 5 January 2005 Accepted 22 March 2005 